\title{
STATITSTICAL ANALYSIS OF CORRECTNESS OF SEAMING CANNED FOOD IN FOOD PRODUCTION WITH THE USE OF STANDARD CONTROL CHART
}

Michał Michałowski ${ }^{\mathrm{a}}$, Sylwia Mierzejewska ${ }^{\mathrm{b}}$, Krzysztof Kukiełka ${ }^{\mathrm{c}^{*}}$, Aldona Baćd, Joanna Piepiórka-Stepuk ${ }^{\mathrm{e}}$

a Department of Production Engineering, Koszalin University of Technology, Poland

b Department of Food Industry Processes and Facilities, Koszalin University of Technology, sylwia.mierzejewska@tu.koszalin.pl, Poland, ORCID 0000-0001-5225-6540

c Department of Production Engineering, Koszalin University of Technology, Poland, krzysztof.kukielka@tu.koszalin.pl, ORCID 0000-0003-2468-2782

d Department of Food Industry Processes and Facilities, Koszalin University of Technology, Poland, aldona.bac@tu.koszalin.pl, ORCID 0000-0003-2032-0477

e Department of Food Industry Processes and Facilities, Koszalin University of Technology, Poland, joanna.piepiorka@tu.koszalin.pl, ORCID 0000-0002-5615-3343

*Corresponding author: e-mail:krzysztof.kukielka@tu.koszalin.pl

\begin{tabular}{l}
\hline ARTICLE INFO \\
\hline Article history: \\
Received: August 2019 \\
Received in the revised form: \\
September 2019 \\
Accepted: December 2019 \\
\hline Key words: \\
canned fish, \\
double seaming, \\
quality control \\
\end{tabular}

\section{ABSTRACT}

The paper presents a study on the control of the canned fish seaming
with the so-called double seam and statistical analysis of correctness
of seaming. The use of standard control charts enabled observation
and intervention in case irrelevant parameters occur to keep the stabil-
ity of the process. Based on the analysis made in Statistica program,
a moment could have been captured when a machine had to be regu-
lated in case the value of parameters of the double seam decreased and
it had to be concluded unanimously when the most important seaming
tools (rolls) should be replaced. A problem that had been solved
consists mainly in ensuring the stability of the process during constant
monitoring of the seaming process of the canned food.

\section{The list of symbols and acronyms}

\section{Symbols}

CP $\quad$ - potential process capability

Cpk - real process capability

$\mathrm{R} \quad-$ range

$\bar{R} \quad$ - averagerange

$\sigma \quad-$ standard deviation

$\bar{x} \quad-$ mean of samples

$\bar{X} \quad-$ mean of averages (averagevalue) 
M. Michałowski, S. Mierzejewska, K. Kukiełka, A. Bać, J. Piepiórka-Stepuk

\title{
Acronyms
}

\author{
DLK - Lower Control Limit \\ DLT - Lower Tolerance Limit \\ GLK - Upper Control Limit \\ GLT - Upper Tolerance Limit \\ SKJ - Statistical QualityInspection
}

\section{Introduction}

Production of food is one of the most requiring processes since its quality is related directly to consumer's health and life. To meet even higher clients' requirements and expectations concerning the quality but also the number of supplied products, it is necessary to consciously use the quality system. The introduced quality systems aim at elimination of threats and maintenance of quality at the highest possible level.

In the fish industry, despite the significant development of packaging techniques, the most popular method of maintenance is pasteurisation and sterilization of fish in cans. Cans for production of food must be long-lasting, tight, resistant to external factors including mechanical damage and resistant to internal pressure. Thanks to the material they are made with, they are easily recyclable which is significant due to the environmental protection (Rybarczyk, 1990). Presently, we deal with steel and aluminium cans with various finishing and thickness. Manufacturing specification of a metal or aluminium can greatly depend on a client since with rising production costs, the packaging price should be the lowest, maintaining at the same time the highest possible quality.

Can seaming is one of the most important operations in the production process of fish cans (Sikorski, 2004). Seaming must be hermetic and thus it should completely isolate the products contained in a can from the atmospheric oxygen and microbiological contaminations. A standard method that guarantees tightness of the seaming is the so-called double seaming. Both the flange of a can and the outside edge of a lid are suitably profiled and overlap (the so-called zip). During pressing of the bottom of a can with a lid to the seaming head, rollers of the seamer form a double seam that should guarantee hermetic closing of cans. A can is considered fully tight only after the process of sterilization, where under the influence of temperature of about $115^{\circ} \mathrm{C}$, except for sterilization of the content, the gum present on the lid gets softer and thus fills in the free space in the zip of the double seam. Thus, a final sealing and therefore sterile connection takes place.

The increase of the speed of production lines (higher performance) and reduction of the sheet metal thickness (lower costs) caused the increase in the need of careful inspection of dimensions of folds to ensure a product safety for consumer's health. The quality of seaming changes as a result of wear and tear of pressing rollers of the seamer head. Monitoring of technological processes gives an opportunity of better understanding and thus reduction of the total elimination of products that are incompliant with the accepted standards. Analysis of the current studies enables a clear conclusion that we can predict the course of the future process thanks to which we are able to improve the level of quality in the enterprise on the up-to date basis. 
Statitstical analysis...

\section{The aim of the paper}

The aim of the paper is verification of the correctness of seaming based on the tests carried out on cans collected from the production line. Analysis of statistical inspection of the process quality was applied with the use of standard control charts. The scope of work included issues related to quality in relation to the production requirements of canned fish and statistical analysis, using standard control charts.

Researchmaterial and methods

The object of the control was a can made of aluminium alloy with an EO lid. Suppliers of cans provide basic information thanks to which a producer of cans can correctly set technical parameters of the machine adjusting it thus to the type of seamed cans. With regard to dimensions and technical specifications cans with a lid are a set. In practice it means that a producer of packaging guarantees suitable adjustment with maintaining proper technical settings of a seamer.

The best method of ensuring the quality of double seams is constant sight control of a device and frequent tests and maintenance of seaming tools (Hosmer and Lemeshow, 2000). Double seaming is a complex process with many variables which may affect the final shape, dimensions, and tightness of a seam. Compliance of a seam with relevant standards may be precisely assessed with three critical parameters (real seam, internal length of the side hook, length of the internal zip) (PN-O-79551:1997).

As a part of ensuring quality one other operational parameters should be measured since based on them one may calculate critical values and determine proper settings. In establishments, a projector for testing of the cross-section of a double seaming and then registration of data is carried out which enables application of the statistical process control. If any of critical parameters is not within the set limits, an action determined in the plan of control must be undertaken. Analysis of operational parameters usually enables identification of an activity which is indispensable for correction of parameters of setting of a double seamforming head.

Based on the analysis of the correctly seamed can, a reference dimensions of seaming were determined which were presented in table 1.

Table 1.

Reference dimensionsof a doubleseaming(own study, based on the HACCP system)

\begin{tabular}{lccccccc}
\hline \multicolumn{7}{c}{ All dimensions in mm unless other units were determined } \\
\hline & Set value & $\begin{array}{c}\text { Scope of } \\
\text { the tolerance value } \\
\text { Machine settings }\end{array}$ & $\begin{array}{c}\text { The scope of toler- } \\
\text { ance during control } \\
\text { of the production } \\
\text { process }\end{array}$ & $\begin{array}{c}\text { Admissible } \\
\text { limits } \\
\text { Minimum }\end{array}$ \\
\cline { 2 - 6 } & Arch parameters & $\begin{array}{c}\text { Straight } \\
\text { line }\end{array}$ & Arch & $\begin{array}{c}\text { Straight } \\
\text { line }\end{array}$ & Arch & $\begin{array}{c}\text { Straight } \\
\text { line }\end{array}$ & Minimurn \\
\hline $\begin{array}{l}\text { Degree of crests } \\
\text { Real seam a }\end{array}$ & $95 \%$ & $95 \%$ & \pm 5 & \pm 5 & $+5 \%$ & $+5 \%$ & $75 \%$ \\
$\begin{array}{l}\text { Percentage of the contact } \\
\text { of the side hook b/c }\end{array}$ & $81 \%$ & $83 \%$ & $\pm 5 \%$ & $\pm 5 \%$ & $\pm 10 \%$ & $\pm 10 \%$ & $70 \%$ \\
\hline
\end{tabular}


The analysis covered seaming of Hansa type cans made on one seamer. Samples of cans were collected every two hours within a period of six months, ,which result from the specifics of the process. In the first month, the process was stable, because the closing rollers are not subject to rapid consumption, and the process required adjustment only after changing the type of produced canned. After replacing the canning closing rollers, in the sixth month, the process was destabilized, especially in the initial period when the closing parameters were adjusted. If any irregularities were found, the sample was taken immediately after adjustment or replacement of the closing rollers, until the correct parameters of the double seam were obtained.

Each sample was given a number and was marked in the points of measurement and crossing (fig. 2). Three basic parameters were calculated: real seam (a), internal length of a side hook (b) and internal length of a zip (c) (Fig.1). 6 samples were collected from each can. Based on the standard and the literature sources, from each can were collected six Samales, as shown in Figure 2 (Czyżewski, 2009).Places of collection were marked in figure 2. A projector for cross-sectional studies was used for quality evaluation of a seam. Based on the results of measurements, analysis with the use of statistical inspection of the process was performed.

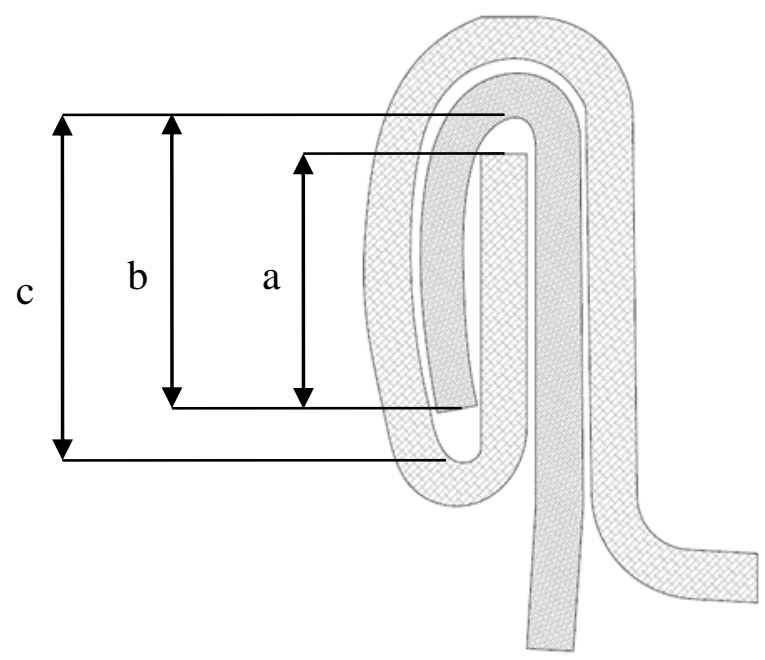

Figure 1. Double seam after seaming: a) real seam b) internal length of the side hook and c) internal length of a zip

\section{Selection of the inspection card and parameters of a sample}

Due to the fact that the quality of cans is directly related to the safety of food, it was concluded that the best and the safest solution will be selection of critical characteristics which will be controlled with charts for numerical evaluation. Because the selected chart concerned an element based on numerical values and the size of the collected sample was 6 , 
Statitstical analysis...

it was decided that it will be R-type chart. The most important examined parameter will be a real seal (a). A range it should be within is $1 \mathrm{~mm}$ (admissible critical seam) up to $1.4 \mathrm{~mm}$ (desired value). A length of the bottom hook (b) and the internal length of a zip (c) will be examined as additional values, where: $\mathrm{a} / \mathrm{c}>45 \%$ while $\mathrm{b} / \mathrm{c}>70 \%$.

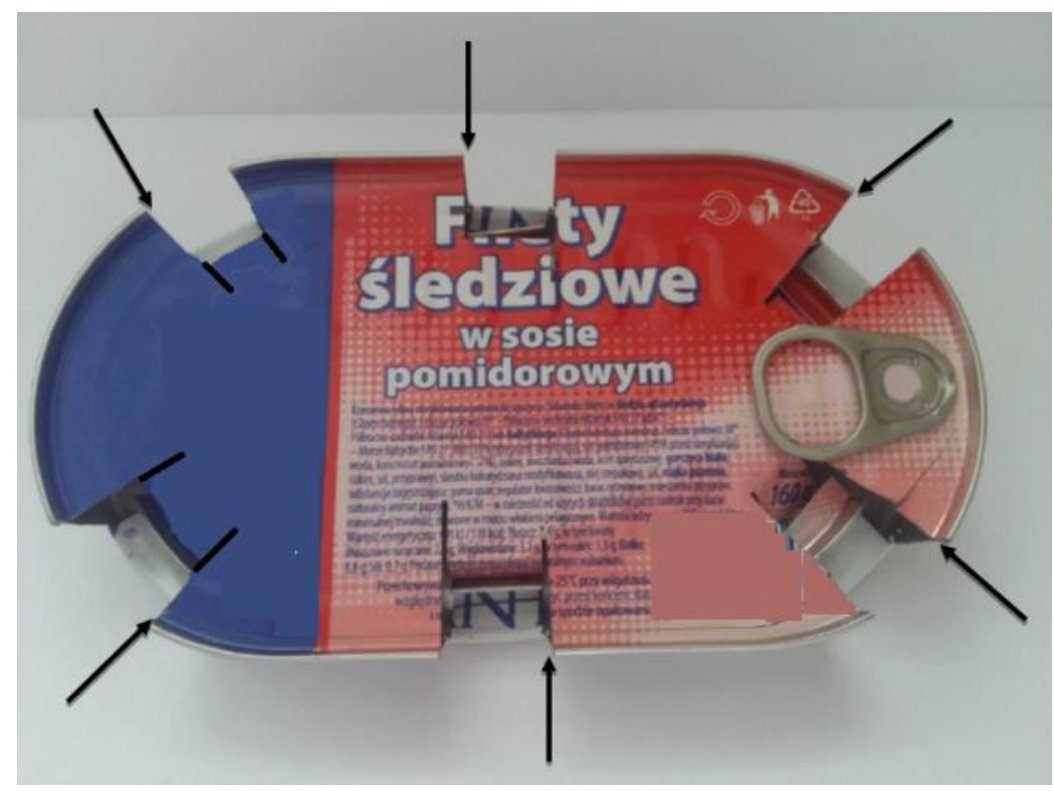

Figure 2. Can with a marked place of sample collection

Based on the obtained values, calculations were made. For $\bar{x}$ chart, the following statistical values were calculated $\overline{x,} \bar{X}, G L K \bar{x}, D L K \bar{x}$. The obtained data were introduced to the Statistica program (Stanisz, 2006). A sheet of the program includes 2 variables - a value of the real seam and numbers and abundance of the sample. The sizes of the real seam are numerical values provided with the precision to 1 decimal while the abundance of a sample is a natural number. A nominal value for the test carried out for all measurements within six months from replacement of the seaming tool is $1.25 \mathrm{~mm}$. The upper control limit $(1.5 \mathrm{~mm})$ and the lower control limit $(0.9 \mathrm{~mm})$ were determined based on the specification of a double seam of a client and a long-term observation of measurements. Due to the fact that the standard dimensions on the arc and straight section do not differ significantly (Table 1), it was assumed that all repetitions at the measuring points of the real seam will be analyzed together.It is known that after replacement of seaming tools parameters of the double seam will be much higher while shortly before another replacement, they are much lower than at the beginning but still meet the requirements of the specification. Alarm limits were determined similarly (upper $1.4 \mathrm{~mm}$; lower $1.0 \mathrm{~mm}$ ) (Michałowski, 2017). 


\section{Results}

In the first week of the first month after the replacement of seaming tools (Fig. 3) a high stability of the process is reported, which is proved by high possible capability of the process $\mathrm{Cp}$ and real capability of the process $\mathrm{Cpk}$. In this sample we may observe a high average of samples at the level of $1.34 \mathrm{~mm}$ (expected values $1.4 \mathrm{~mm}$ ) which proves that a can was seamed very well. The highest number of measurements was obtained within 1.3 to $1.34 \mathrm{~mm}$, there are no measurements below $1.2 \mathrm{~mm}$ which allow to conclude that the batch produced within the first month is particularly good on account of quality. Single signals of reduction of the seaming quality were controlled and meant changes in the order that were related to the change in the canned fish and a change of packaging producer. In relation to a slight change there was no regulation and interference in setting of a seamer.

When comparing analysis for the first week after a change of seaming tools (Fig. 3) and analysis of the first week in the sixth month (Fig. 4) we may observe a slight reduction of $\mathrm{Cp}$ and Cpk.

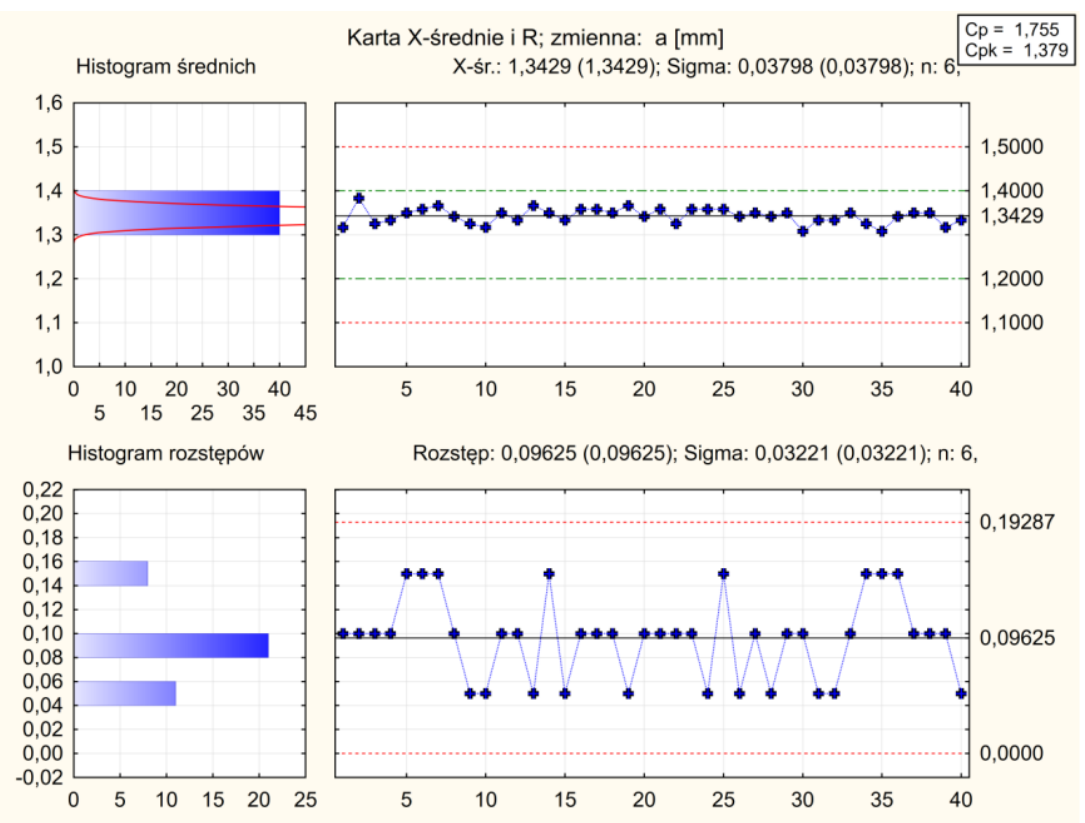

Figure 3. Standard control chart for $x$-average and $R$ - range for results in the first week of using after replacement of seaming rollers 
Statitstical analysis...

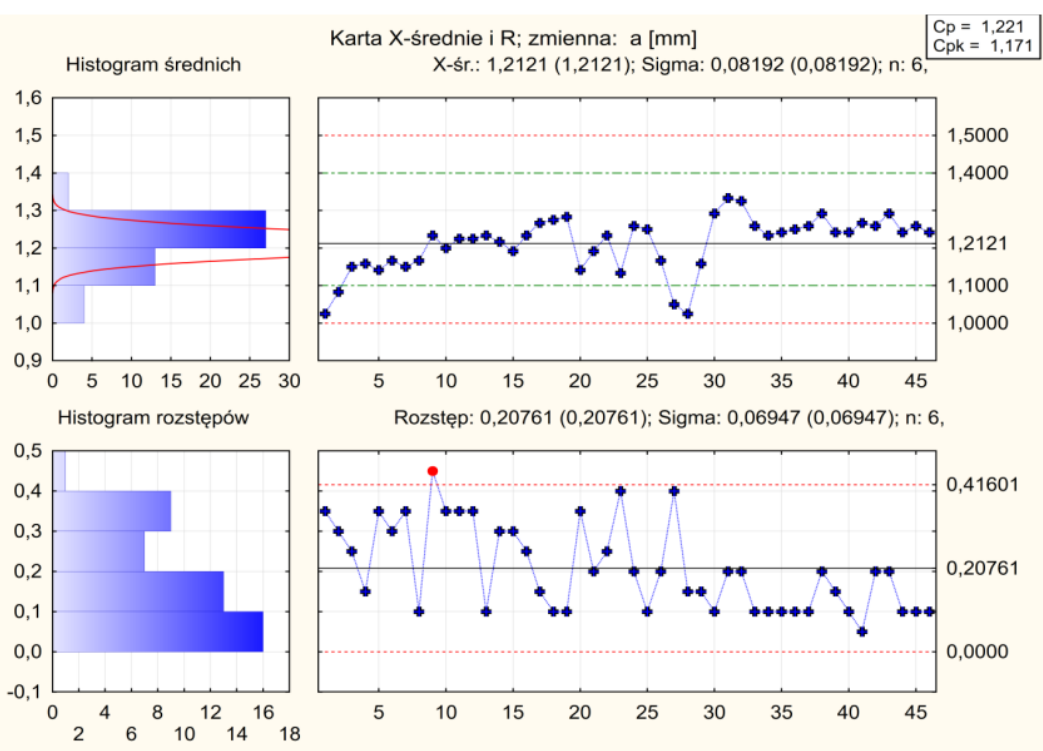

Figure 4. Standard control chart for $x$-average and $R$-range for results in the sixth month of using after replacement of seaming rollers

Both values despite the reported reduction still prove the stability of the process. The average value has changed from 1.34 to 1.21 . Observation of the decrease of values indicates the consumption of the seaming tools which may be proved based on the long-term experience of a mechanic that controls the quality of seaming. In case of the analysis (fig. 4) in the sixth month it is clear that despite the regulation which was performed immediately after observing deviations of the machine even more measurements estimate within 1-1.1 mm. Unfortunately, also even more often we may observe measurements 0.9 which disqualify the correct seaming. Regulations enabled for a specific period of time to obtain a seam at the level above 1.0; however, even more often signals prove the need of replacing the seaming rollers.

\section{Discusion}

Statistical analysis, based on standard control charts $\mathrm{x}$-medium and $\mathrm{R}$ range can be successfully used in the canned production, receipted on the production line. The 6-month observations show that the process stability is at a high level as evidenced by the high value of process capability indicators, however, in the later stages of the closing machine operation, the closing tool is consumpted, and thus the xśr, $\mathrm{R}$ as well as the Cp and Cpk parameters decrease. In the future, research on the impact of pre-treatment parameters of sheet metal intended for canned Hansa on double seam parameters should be expanded, which are also important in this case. 


\section{Conclusion}

The paper presents verification of correctness of seaming based on the research with the use of statistical analysis with the use of standard control charts. Based on the presented requirements for seaming of cans for food production with a special attention paid to the parameters of the double seam, one may conclude that the use of standard control charts enables observation and in case of parameters which are not compliant with the intervention in order to maintain the process stability. The developed control chart for numerical assessment and analysis of the process capability carried out based on this with maintenance of the quality of seaming cans enabled the control of the seaming quality and proper procedure in case of dysregulation. Closing machine adjustments, made shortly after observing the deviations and replacing closing tools in the sixth month, maintained the canning process at the correct level.The undertaken regulations of the seamer and replacement of seaming tools maintained the process of seaming cans at the correct level. A control chart was prepared for the measurements of the real seam in produced cans, for which a statistical quality control of the process was carried out. Data obtained by Statistica by analysis were indispensable for correct reaction to the course of the production process. Based on the obtained results one may state that approx. 4.2 million of cans produced on the controlled seamer meet the quality standards assumed by the company and may be admitted for sale on the food market.

Based on the analysis made in Statistica, one could have caught moments, when the machine had to be regulated in case of the decrease of the seaming parameters and it should have been concluded clearly when the most important seaming tools are qualified for replacement. The problem that was solved consists mainly in constant monitoring of the process of seaming cans. The statistical quality control guarantees the solution of the problem of clients' complaints since the actions are taken immediately after signals that prove the reduction of the quality of the can seaming process preventing thus an incompliant product to be manufactured. The use of the statistical quality control reduced also the production costs since it limits or completely eliminates occurrence of faulty batches, reduces the costs of utilization or improvement of the faulty batch and thus enables obtaining a product that is compliant with the accepted standards.

\section{References}

Czyżewski, B. (2009). Metody statystyczne w sterowaniu jakościa procesów. Wielkopolski Klub Jakości FSNT NOT.

Hosmer, D.W., Lemeshow, S. (2000). Applied logisticl regression: Second Edition, New York John Wiley \& Sons, USA.

Michałowski, M. (2017). Analiza statystyczna prawidłowości zamknięcia konserw w produkcji spożywczej przy wykorzystaniu standardowych kart kontrolnych. Praca dyplomowa inżynierska, Politechnika Koszalińska, Wydział Mechaniczny, Koszalin 2017.

PN-O-79551:1997 Opakowania jednostkowe metalowe - puszki do artykułów żywnościowych konserwowych - ogólne wymagania i metody badań

Rybarczyk, S. (1990). Technologia obróbki i przetwórstwa ryb. Szczecińskie Wydawnictwo Diecezjalne Ottonianum, Gniezno, Poland $b$

Stanisz, A. (2006). Przystępny kurs statystyki w oparciu o program Statistica PL na przyktadach z medycyny. Wydawca StatSoft Polska, Kraków. ISBN 83-88724-18-5 


\section{ANALIZA STATYSTYCZNA PRAWIDLOWOŚCI ZAMKNIĘCIA KONSERW W PRODUKCJI SPOŻYWCZEJ PRZY WYKORZYSTANIU STANDARDOWYCH KART KONTROLNYCH}

Streszczenie. W pracy przedstawiono badania dotyczące kontroli zamknięcia konserw rybnych na tzw. podwójną zakładkę i analizę statystyczną prawidłowości ich zamknięcia. Zastosowanie standardowych kart kontrolnych pozwoliło na obserwację oraz interwencję w przypadku wystąpienia parametrów niezgodnych, w celu utrzymania stabilności procesu. Na podstawie analizy wykonanej w programie Statistica, można było wychwycić momenty, w których należało dokonać regulacji maszyny w przypadku spadku wartości parametrów podwójnej zakładki, a także stwierdzić jednoznacznie, kiedy najważniejsze narzędzia zamykające (rolki) kwalifikują się do wymiany. Problem jaki udało się rozwiązać, to przede wszystkim zapewnienie stabilności procesu w trakcie ciągłego monitoringu procesu zamykania konserw.

Słowa kluczowe: konserwy rybne, zamknięcie na podwójną zakładkę, kontrola jakości 